\title{
THE EFFECT OF CONCENTRATIONS OF BENTONITE ON THE PROPERTIES OF NON-NEWTONIAN FLUIDS
}

\section{Eman Salah Abdulwahab}

dodi_princess1993@yahoo.com
Muhanned A.R.Mohammed

alobaidyhussien@gmail.com

\section{ABSTRACT}

This research study the properties of Non-Newtonian fluids. Eight samples of Non-Newtonian fluids were prepared, with constant concentration of Carboxy methyl cellulose (CMC) which was $(2 \mathrm{gm} / 500 \mathrm{cc})$, and different concentrations of weighting material (Bentonite). The concentrations of Bentonite were $(8,10,12,20,26,32,36,42)$ grams with $500 \mathrm{ml}$ water. It was concluded that the increase in the concentration of Bentonite will increase the shear stress with the increase of shear rate. It was also concluded that the increase in the concentration of Bentonite will increase the plastic viscosity, yield point, and density of these Non-Newtonian fluids.

Key word: Non-Newtonian fluids, weighting materials.

$$
\begin{aligned}
& \text { تأثير تراكيز البتنونيت على مواصفات الموائع اللانيوتونية } \\
& \text { ايمان صلاح عبد الوهاب مهند عبد الرزاق محمود } \\
& \text { جامعة النهرين /كلية الهندسة/قسم الهندسة الكيمياوية }
\end{aligned}
$$

تم في هذا البحث در اسة خصائص السو ائل غير النيوتونية. تم تحضير ثماني عينات من السو ائل غير النيونونية ، مع تركيز

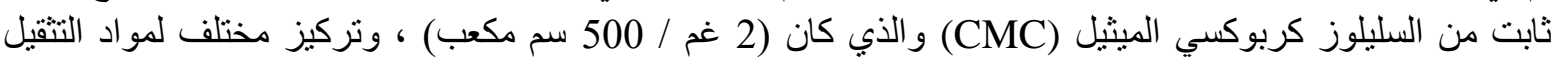

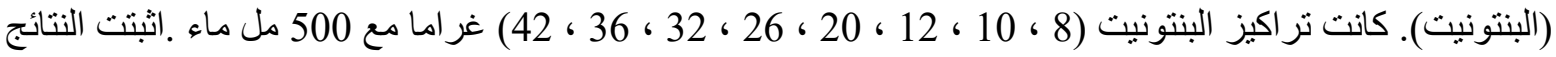

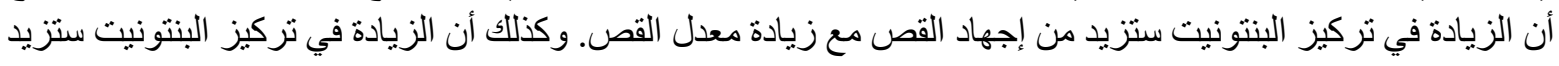

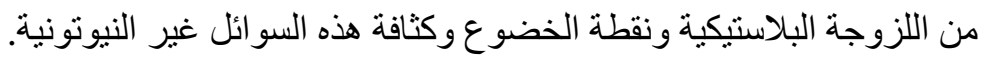


NOMENCLATURE

$\tau$ Shear stress $\left(\left(\mathrm{Ib} / 100 \mathrm{ft}^{2}\right)\right.$

$\gamma$ Shear rate $(1 / \mathrm{sec})$ or sec $^{-1}$

PV Plastic viscosity ( CP )

YP Yield point $\left(\mathrm{Ib} / 100 \mathrm{ft}^{2}\right)$

$\mathrm{n} \quad$ Flow behavior index

\section{INTRODUCTION}

Rheology is the learning on the deformation then flow over matter, on occasion referred to namely "the flow characteristics" on the liquid and such is the same meaning. Also will be able defined as like such is the instruction concerning the relation between shear stress and shear rate [Chhabra and Richardson,1999]. The aim of this research is to prepare NonNewtonian fluids and study the effect of weighting material (Bentonite) on its properties. Newtonian fluids are these among which the viscosity stays steady for all shear rates providing pressure and temperature conditions stay constant. Examples concerning Newtonian fluids are : water, benzene, light oil and many solutions that have simple molecules [Holland,1995]. Non-Newtonian fluids do not exhibit a direct proportionality between shear stress and shear rate. The ratio of shear stress to shear rate changes with shear rate and the ratio is defined as "effective viscosity". But this shear rate have to keep identified for each effective viscosity value. When it was plotted shear stress versus shear rate, a non straight line outcome. Some of them pass through the origin and the other not. Because the ratio differs at each shear rate [Holland,1995]. Benchabane et al. [2008], studied the way of predicting two critical concentrations of sodium Carboxy methyl cellulose (CMC) solutions using simple experimental procedures with a rotational rheometer. It was found that, above a critical shear rate, all CMC solutions $(0.2$ to 7 wt. $\%)$ exhibit shearthinning behavior and the flow curves could be described by the Cross model. It was found that no yield stress was observed for the aqueous solutions of CMC. The experimental results were found to be well correlated by the Cross model. The Cross parameters, i.e., zero shear rate viscosity, $\mu 0$, and reciprocal of the time constant, allowed the determination of the critical concentration. Lee et al. [2006], studied the effect of cellulose treatments on the rheology of Carboxy methyl cellulose (CMC) solutions using a rotational viscometer. The rheological behavior of anionic cellulose derivatives during the course of enzyme hydrolysis has been investigated. The effects of the active and heat-denatured celluloses, and a cationic polyelectrolyte (C-PAM) have been examined. Cellulose derivatives with different degrees of polymerization and substitution were examined. A polymeric effect, defined as a reduction in viscosity of the CMCs without significant formation of reducing sugars released from the degradation of the CMCs by enzymatic hydrolysis, has been observed in this study. Ghannam et al. [1998], studied the rheological properties of Carboxy methyl cellulose (CMC) solutions. The study was carried out using the computer controlled Rheo Stress RS100 system of Haake. CMC concentration in the test solutions ranged by weight from 1 to $5 \%$. This range was sufficiently wide to reveal the nearly Newtonian behavior at the lower end of concentrations, and the definitely pseudo plastic, thixotropic, and viscoelastic behaviors of CMC solutions at the higher end of concentrations. The scope of the study included measurements of steady state parameters, transient shear stress response, and yield stress. In addition, the thixotropic, creep recovery, and dynamic responses of solutions with high concentrations were measured. 


\section{THEORY}

Yield point: Is the second part regarding thinned arrest after flow, who is a metering regarding the electrochemical forces, then appealing army in sure particles so much encountered among the suspensions submit with the flow conditions. These legions are result regarding terrible then nice prices positioned about then near the floor on consolidated. The cause point relies upon on: The surface properties about suspension's solids. Concentration concerning suspension's solid. And the electric environment of the strong particles [William, 2006]. Yield point can be determined using the following equation:

$$
\text { yield point }(\mathrm{Yp})=\text { shear stress at } 300 \mathrm{rpm} \text { - Plastic viscosity }
$$

The plastic viscosity is the shearing force between extra of generate point of yield point $(\mathrm{Yt}=3 \backslash 4 \mathrm{Yp}$ ) that may produce a unit rate of shear. This is a part of fluid that is resist to flow which is caused by mechanical friction that may occurs by: Between the solid that is found in the fluid. Between the solid and the liquid that is surround of them. And the shearing of liquid itself may be cause [William,2006]. Plastic viscosity can be determined using the following equation:

Plastic viscosity $(\mathrm{Pv})=$ shear stress at $600 \mathrm{rpm}$ - shear stress at $300 \mathrm{rpm}$

Some fluids display change in viscosity with time, under conditions of constant shear rate. Time dependent fluid behavior may be further sub-divided into two categories: Thixotropic and Rheopectic. Thixotropic thin undergoes decrease among viscosity with time, while such subjected to constant shearing. Such conduct, where structures so seem instead solid like but upstairs diligent come to be thinned like, including lowering viscosity, is called thixotropy. At relaxation the slip stability will increase again. A good example and knowing of this type of fluids like a Gypsum suspension. In rheopectic fluid the viscosity was increased with time when the shear was at constant rate. The apparent viscosity was increased with the shear rate, the effect was called the Rheopecty. Other non- Newtonian fluids does not change in shear stress with time under conditions of constant shear rate, called Time-Independent fluids. These fluids may be divided into three categories; pseudo-plastic, Bingham plastic, and Dilatant. The rheological parameters of Bingham plastic fluids are the plastic viscosity and yield point as shown in equation ( 1 ):

$$
\tau=Y p+P v y
$$

While The rheological parameters of pseudo-plastic and Dilatant fluids, are the flow behavior index (n) and the consistency index (k) as shown in power law, equation ( 2 ):

$$
\tau=k \gamma^{n}
$$

Polymers were a large organic molecules composed of extracts seed such as (guar, starch), modified cellulose such as (CMC , HEC) ,biosynthetic gums like (Xanthan), and synthetic polymers like (PVA). Polymers are both linear or branch. In linear polymers, the macromolecules is a lengthy singular chain about monomer units. The linear polymers are both "homo polymers" as are containing repeat units over solely some chemical contract, yet "copolymers" as are containing twins yet greater repeating units. The selection of the best polymers in application can be depends on: The cost of polymer, and the performance of the polymer [Codex, 2016]. CMC is a cellulose spinoff including car boxy methyl companies (-CH2-COOH) sure according to partial regarding the hydroxyl companies on the Glucopyranose monomers as edit upon the cellulose backbone. It is synthesized by means of the alkali-catalyzed response concerning cellulose along Chloroacetic acid. The polar (organic acid) carboxyl organizations render the cellulose soluble then chemically reactive [Codex, 2016]. The useful properties concerning CMC depend over the dosage over substitution about cellulose structure, so toughness properly as much band measure of cellulose backbone shape or the dosage about clustering over Carboxymethyl substituent's 
[Hollabaugh, 1945]. The Bentonite was viewed by Grim (1968) as is earth credit comprising in truth over smectite minerals commonly by means of montmorillonite which has at all extensive extent about manufacturing applications. Among the smectite group , montmorillonite is the almost important commercially with joining predominant types: $\mathrm{Na}-$ Bentonite (Swelling Bentonite): characterized with the aid of expansion on in accordance with 15 times on unique aggregation so immersed among water. $\mathrm{Ca}$ - Bentonite (Non-Swelling Bentonite): characterized with the aid of theadsorption worship but function not exhibit expansion so combined with water. It has the ability according to paint with in lots or has absolutely large spread within nature [Nawasreh, 2015].

\section{EXPERMENTAL WORK}

\section{Experimental Apparatus}

The devices that were used in this work : Fann VG-Viscometer, Hamiltion Beach Mixer and cup, Electronic Balance, and Mud Balance. The Fann viscometer 36 is prescribe reading instrument who has seven speeds : $(6,30,60,100,200,300,600 \mathrm{rpm})$. As proven in such is a coulette coaxil tube viscometer so much allows the version about shearing stress with shear rate after lie observed .A bib suspended structure a spring hangs concentrically between an a goblet on solution, or the sordid tube rotated speed. The viscosity draw floor about the bob shear stress at the answer grew to become the burned till balance through the torque in the spring. The turn regarding the bob is studying beside a calibrated dial about the top of the instrument, for this reason offers a pardon on a force at the floor on the bob [Darely, 1988]. A mud balance is a device old in the imitation of measurement the solidity (weight) concerning fluid or any type on melted yet slurry, such consists on a graduated filament with a bubble stage, and a ounce slider along its extent or a death cup along a basket over some end. The joke is ancient inconformitywith keep a constant total about softened and it may stand weighed. A slider-weight do stay on side the beam, and a bubble suggests then the fiber is level [Chilingar, 2013]. Density is read at the point where the slider-weight sits on the beam at level.

\section{The used materials}

Water, CMC (Carboxy methyl cellulose) is supplied from Qingdao Great Chemical Inc. (China) and Bentonite were used in this work.

\section{Experimental procedure}

Certain amounts of Bentonite $(8,10,12,20,26,32,36$ and 42) grams were added to the $500 \mathrm{ml}$ of water for mixing, then ( $2 \mathrm{gm})$ of $\mathrm{CMC}$ were added, mixing was done using Hamiltion beach mixer. Repeat the same procedure for each amount of Bentonite to prepare the required concentrations, with constant weight of CMC. Measured the shear stress at each shear rate in viscometer. And the density was calculated by Mud Balance.

\section{RESULTS AND DISCUSSION}

\section{Shear stress \& Shear rate}

The shear stress was measured at each shear rate using a Fann VG meter, at each concentration of Bentonite. Figures from(1) to (8) show the relationship between shear stress and shear rate at each concentration of Bentonite. From these figures it can be noticed that the shear stress increase with increasing of shear rate. Whenever concentration of Bentonite increase, shear stress increase at each shear rate. 


\section{Plastic viscosity}

As shown in Figure(10), the increase in the concentration of Bentonite will increase the plastic viscosity, this is due to that the increase in the concentration of solid material will increase the plastic viscosity.

\section{Yield point}

As shown in Fig(11), the increase in the concentration of Bentonite will increase the yield point, this is due to that the increase in the concentration of solid material will increase the yield point.

\section{Density}

Figure(12) shows that the density increases with the increasing of concentration of Bentonite

\section{CONCLUSIONS}

The following conclusions may be drawn from this research :

1- It was found that the shear stress increases with increasing of shear rate for each Bentonite concentration .

2- It was found that the yield point, plastic viscosity, and density increased with increasing of concentration of Bentonite. 


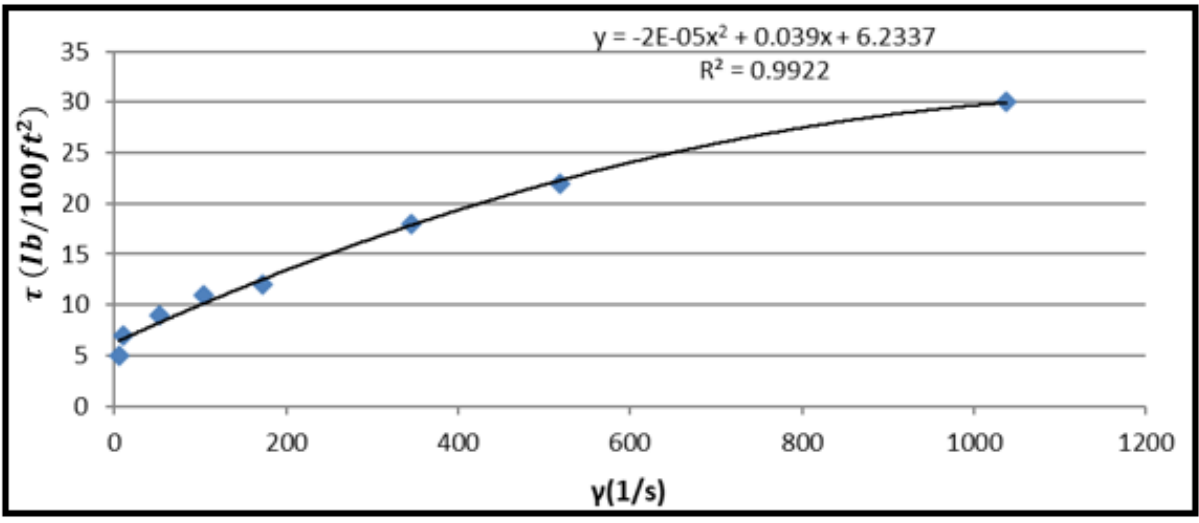

Figure (1): Variation of shear stress with shear rate for $(8 \mathrm{gm} / 500 \mathrm{ml})$ concentration of Bentonite.

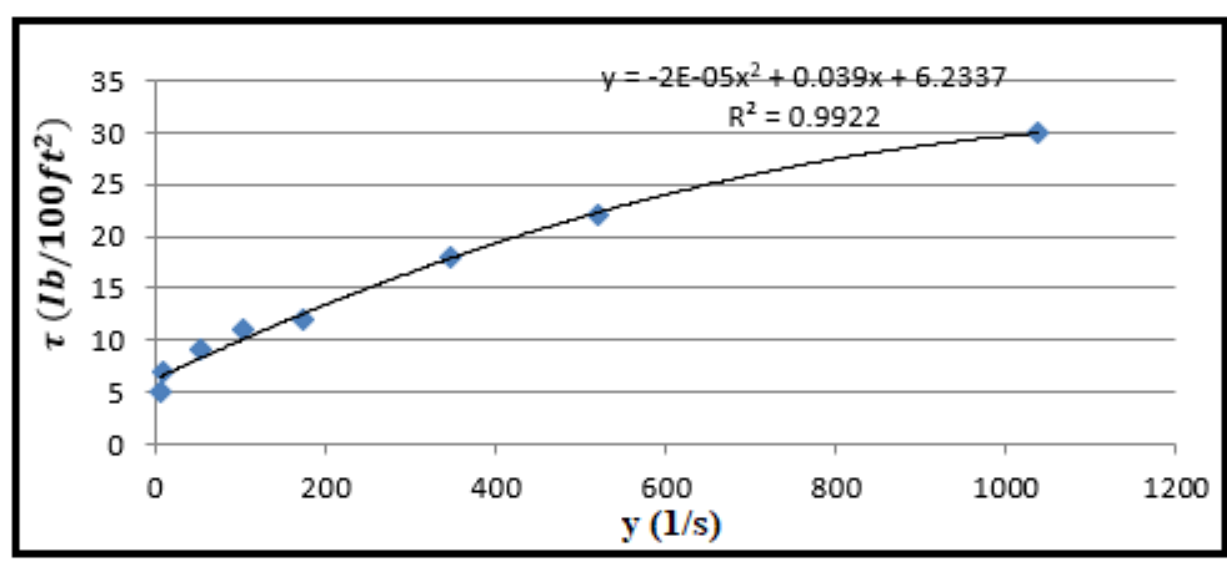

Figure (2): Variation of shear stress with shear rate for $(10 \mathrm{gm} / 500 \mathrm{ml})$ concentration of Bentonite.

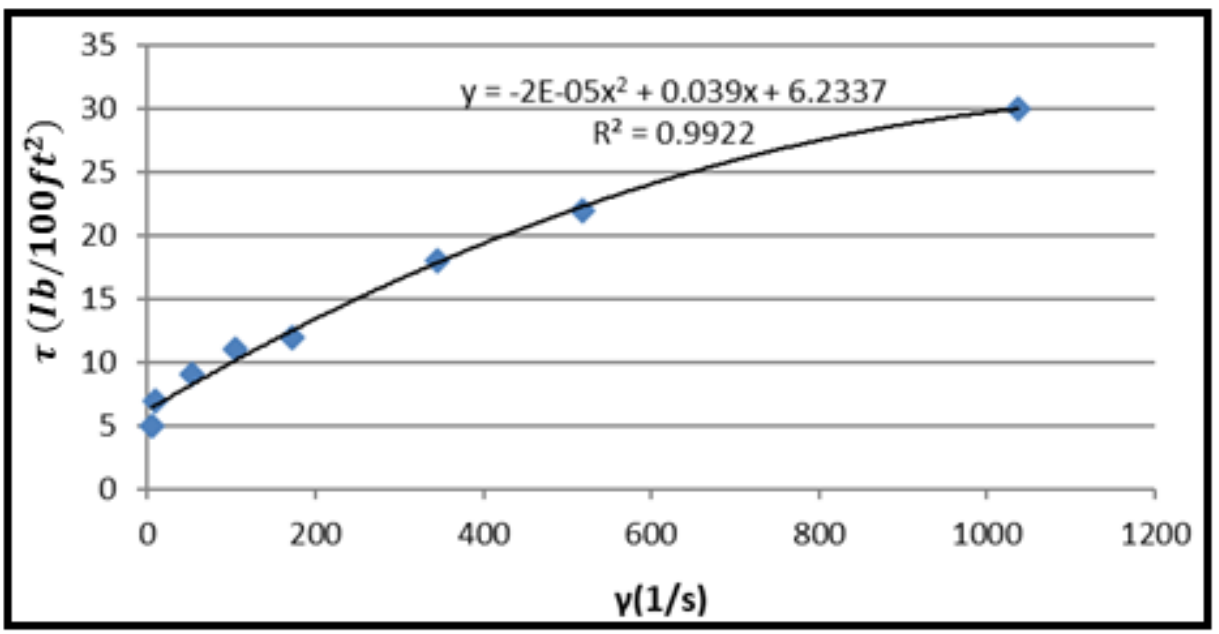

Figure (3): Variation of shear stress with shear rate for $(12 \mathrm{gm} / 500 \mathrm{ml})$ concentration of Bentonite. 


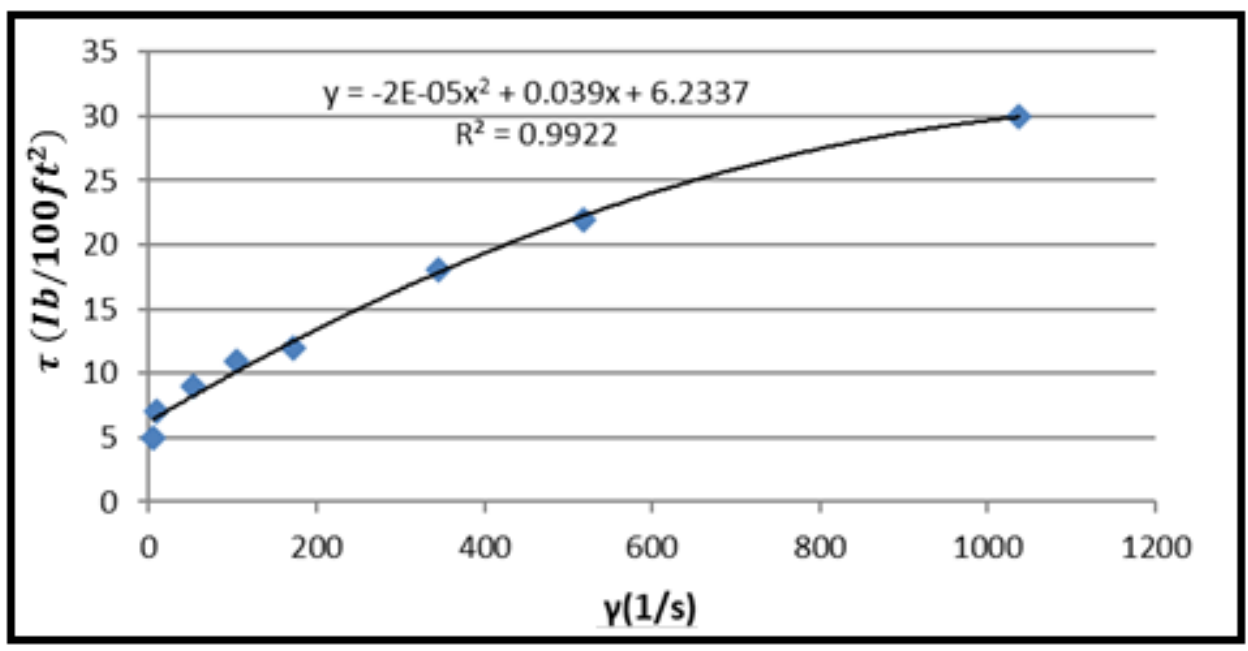

Figure (4): Variation of shear stress with shear rate for $(20 \mathrm{gm} / 500 \mathrm{ml})$ concentration of Bentonite.

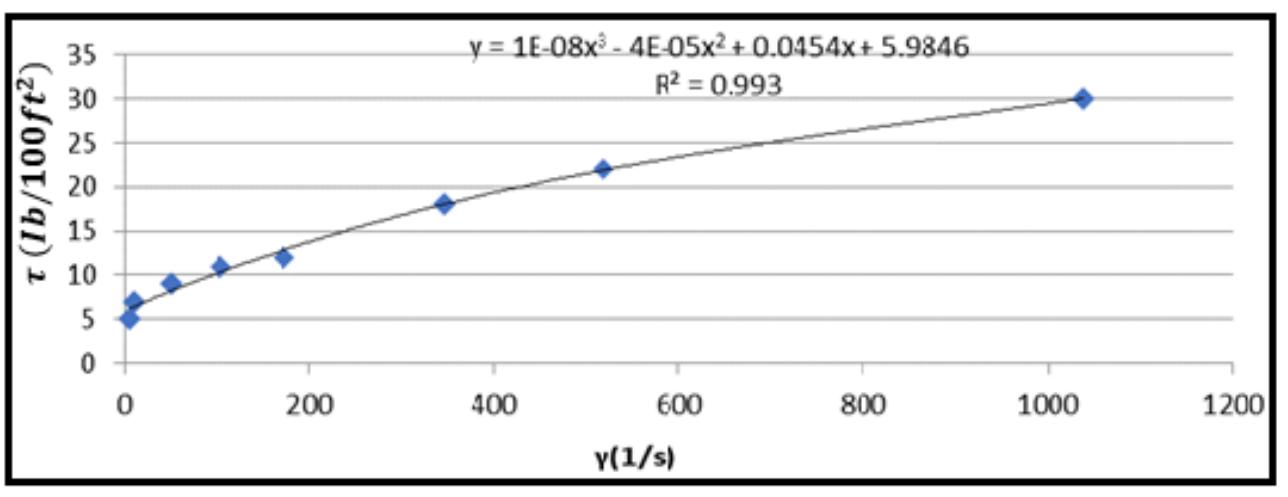

Figure (5): Variation of shear stress with shear rate for $(26 \mathrm{gm} / 500 \mathrm{ml})$ concentration of Bentonite.

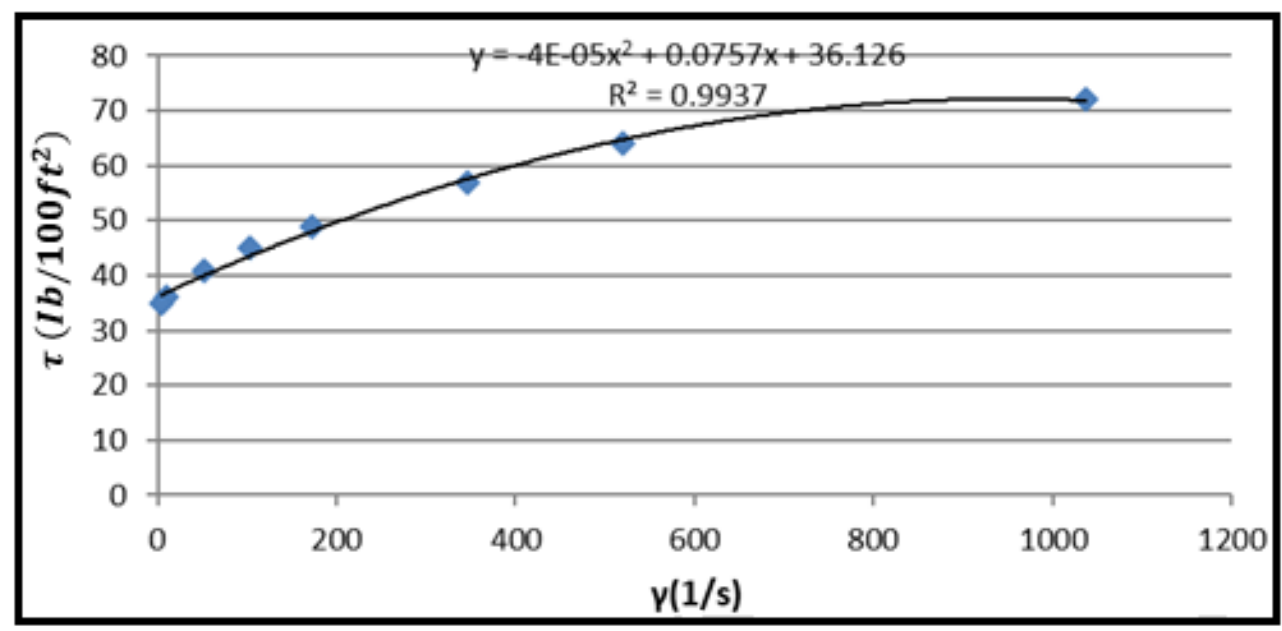

Figure (6): Variation of shear stress with shear rate for $(32 \mathrm{gm} / 500 \mathrm{ml})$ concentration of Bentonite. 


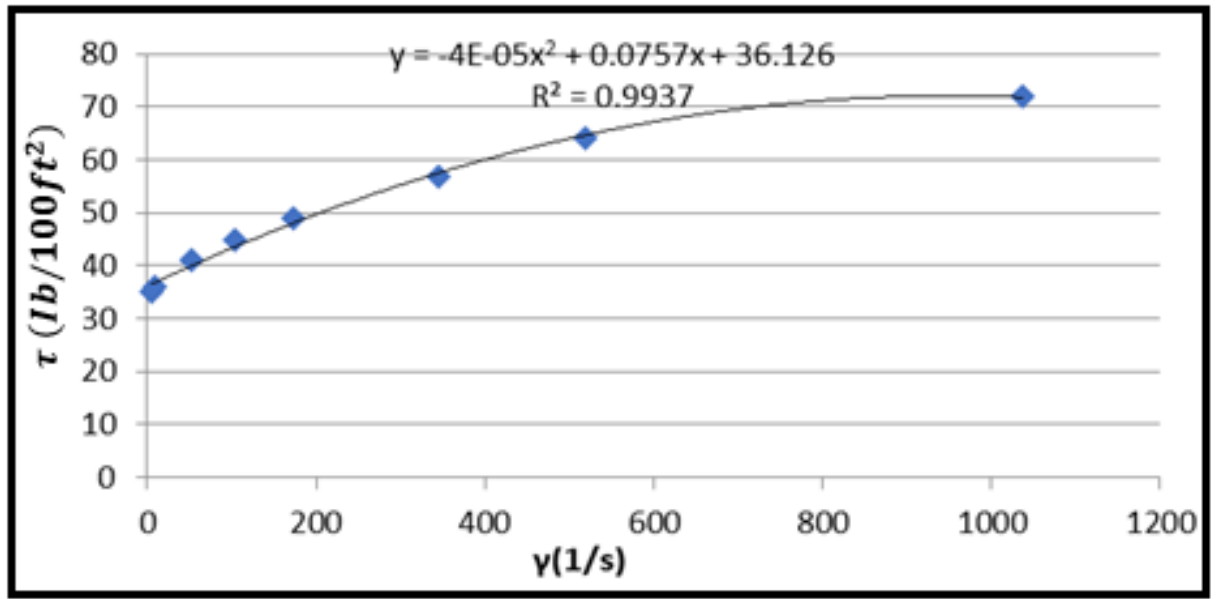

Figure (7): Variation of shear stress with shear rate for $(36 \mathrm{gm} / 500 \mathrm{ml})$ concentration of Bentonite.

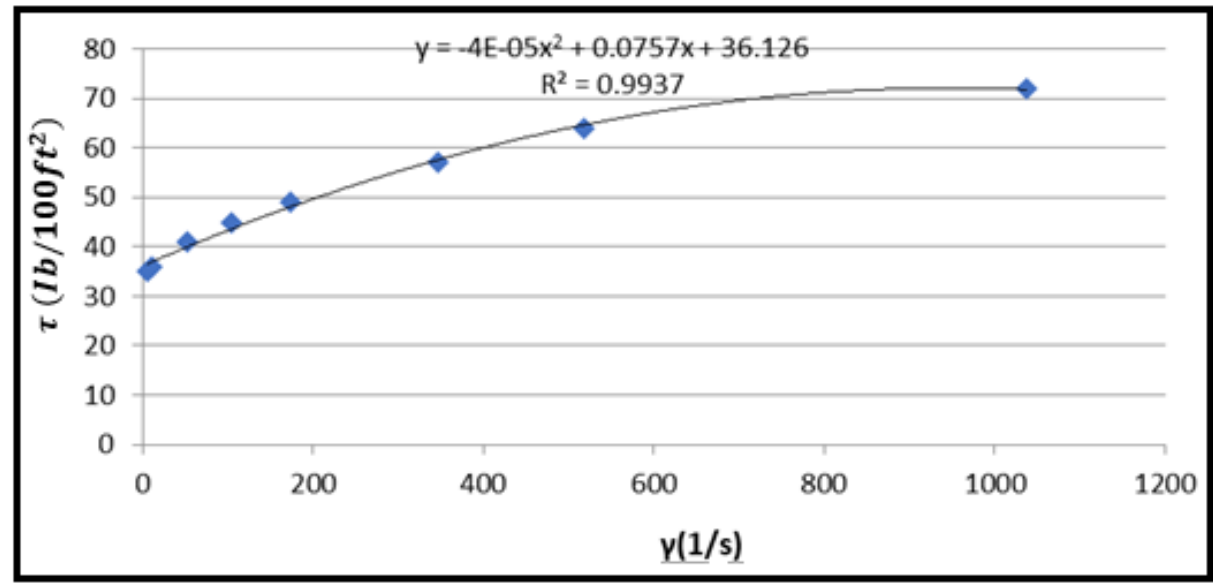

Figure (8): Variation of shear stress with shear rate for $(42 \mathrm{gm} / 500 \mathrm{ml})$ concentration of Bentonite.

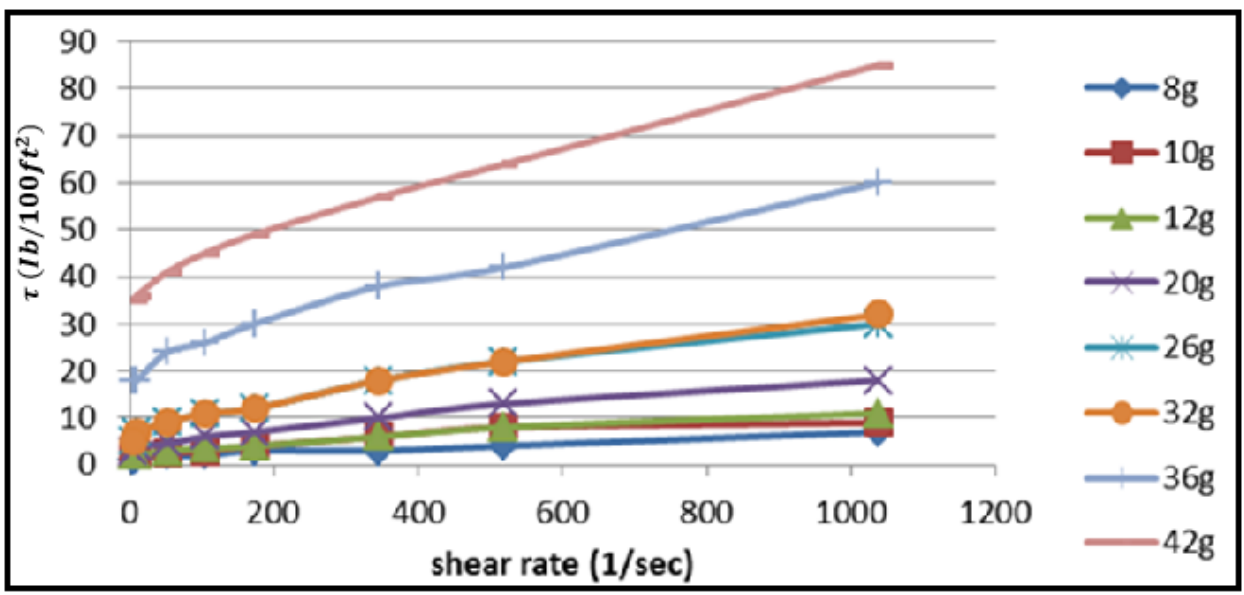

Figure (9): Variation of shear stress with shear rate for all concentration of Bentonite. 


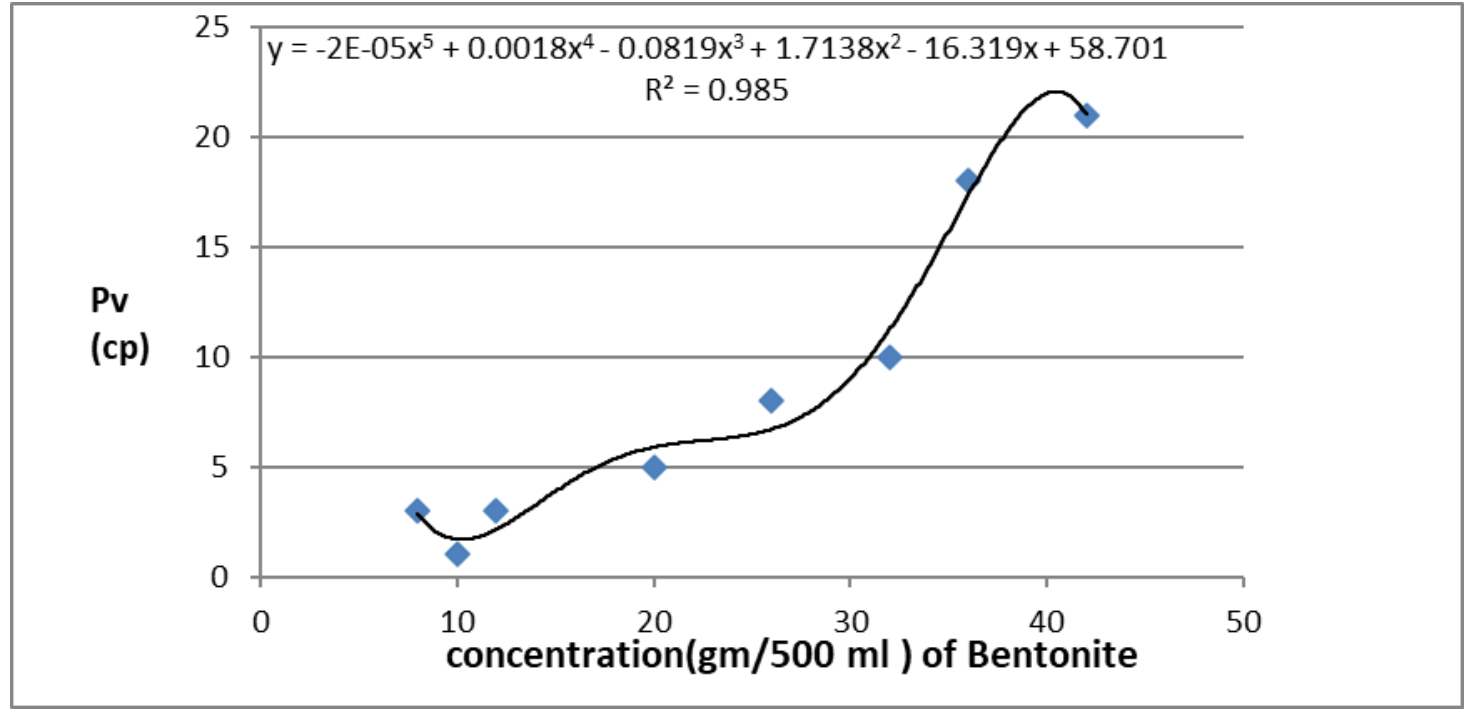

Figure (10): Effect of concentration of Bentonite on plastic viscosity.

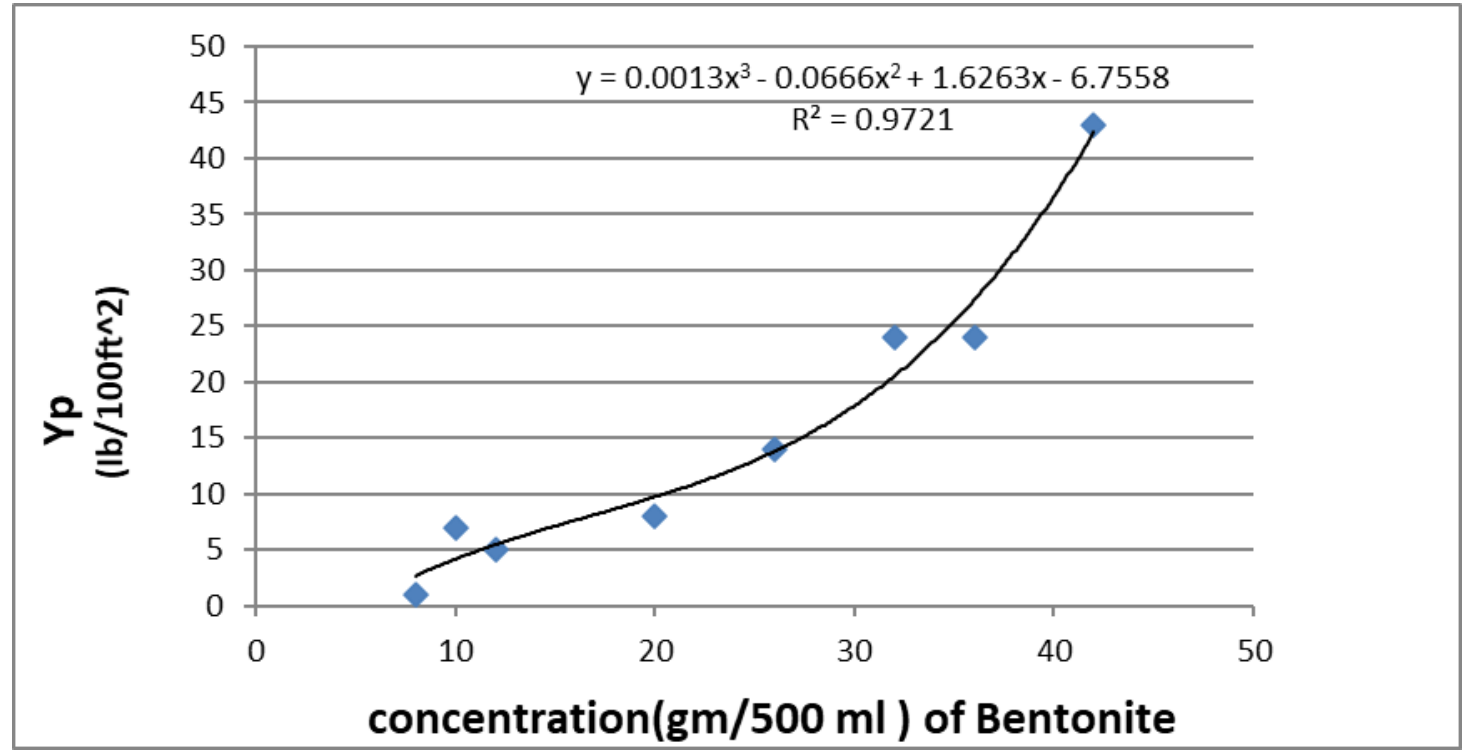

Figure (11): Effect of concentration of Bentonite on yield point.

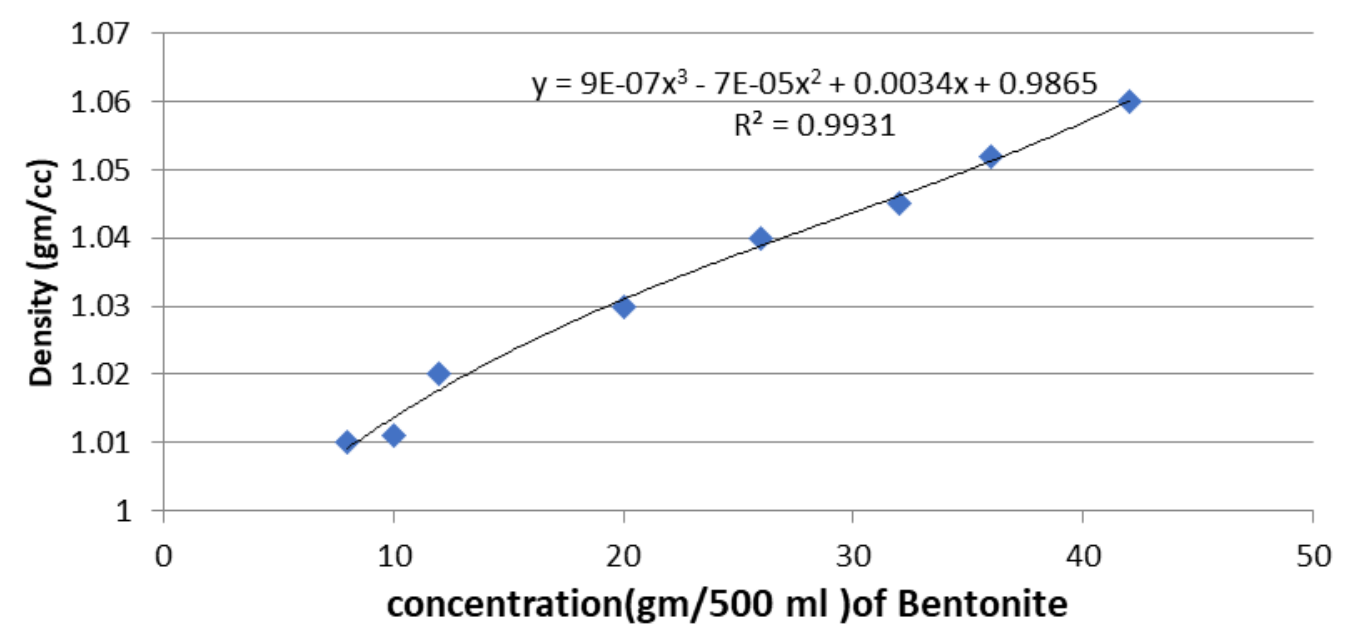

Figure (12): Effect of concentration of Bentonite on density. 


\section{REFERENCES}

Benchabane, A. , Karim, B. Reological properties of Carboxy methyl cellulose (CMC) solutions, Journal of colloid polymer science, 2008.

Chhabra, R. P., and Richardson, R., Non Newtonian flow in process industries , Elsevier publishing Ltd., 1999.

Chilingar, G. V., Paul, V., Drilling and drilling fluids Henn, Raymond W. AUA guidelines for backfilling and contact grouting of tunnels and shafts, 2003.

Codex, A. C., Sodium carboxymethyl cellulose (Cellulose gum), 2016.

Darely, H. C. H., Gray, G. R., Composition and properties of drilling and completion fluid, 5th edition, 1988.

Ghannam, M. T., Esmail, M. N., Rheological properties of carboxy methyl cellulose , Journal of Applied polymer, 1998.

Hollabaugh, C. B., Burt, L. H., Walsh, A. P., Carboxy methyl cellulose... Uses and Applications, Industrial and Engineering Chemistry, 1945.

Holland, F. A., Fluid flow for chemical engineers, Arnold, 1995.

Lee, J. M., H., J. A., Pawlak, J. J., Rheology of carboxy methyl cellulose solution treated with cellulose, Journal of Peer-Reviewed Article -ncsu. edu / bioresources, 2006.

Nawasreh, M., Al-Omari, Y., Ministry of energy and minerals status and future opportunity, Bentonite, 2015.

William L. H., Encyclopaedia Britannica, Yield point, 2006. 